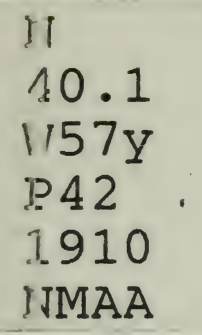





\section{SEVENTH EDITIOON}

THE DE VIVNE PRESS 


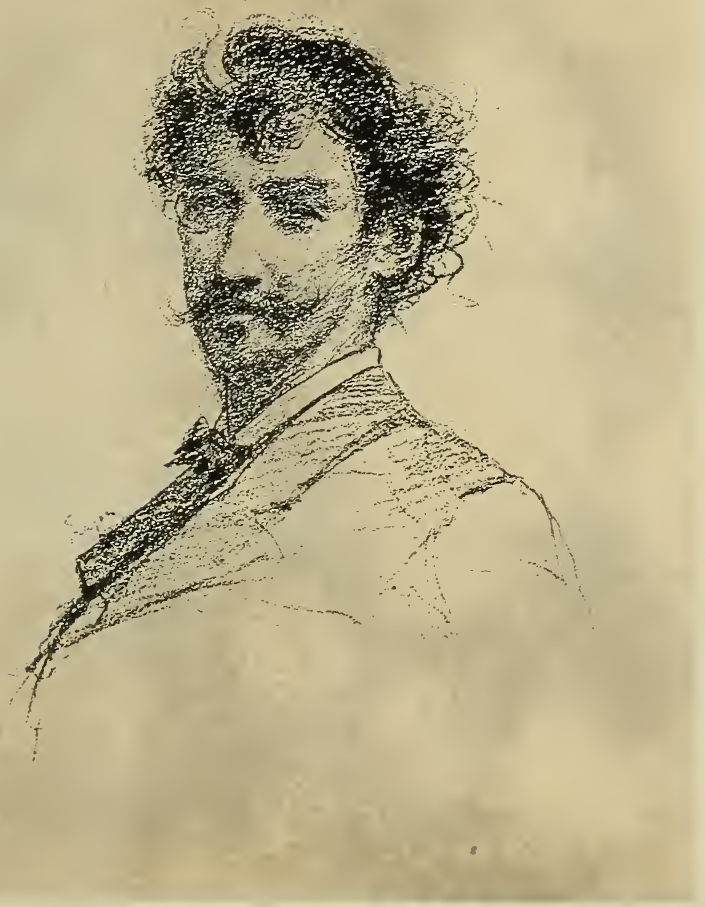

Portrait of Whistler.

From the drawing by Paul Rajon. 

PROPOSITIONS BY MR. WHISTLER REPRINTED FROM HIS BOOK, "THE GENTLE ART OF MAKING ENEMIES."

I. That in Art it is criminal to go beyond the means used in its exercise.

II. That the space to be covered should always be in proper relation to the means used for covering it.

III. That in etching, the means used, or the instrument employed, being the finest possible point, the space to be covered should be small in proportion.

IV. That all attempts to overstep the limits insisted upon by such proportions are inartistic thoroughly, and tend to reveal the paucity of the means used, instead of concealing the same, as required by Art in its refinement.

$V$. That the huge plate, therefore, is an offense-its undertaking an unbecoming display of determination and ignorance-its accomplishment a triumph of unthinking earnestness and uncontrollable energy-endowments of the "duffer." 
VI. That the custom of "Remarque" emanates from the amateur, and reflects his foolish facility beyond the border of his picture, thus testifying to his unscientific sense of its dignity.

VII. That it is odious.

VIII. That, indeed, there should be no margin on the proof to receive such "Remarque."

IX. That the habit of margin, again, dates from the outsider, and continues with the collector in his unreasoning connoisseurshiptaking curious pleasure in the quantity of paper.

$X$. That the picture ending where the frame begins, and in the case of the etching, the white mount, being inevitably, because of its color, the frame, the picture thus extends itself irrelevantly through the margin to the mount.

XI. That wit of this kind would leave six inches of raw canvas between the painting and its gold frame, to delight the purchaser with the quality of the cloth. 


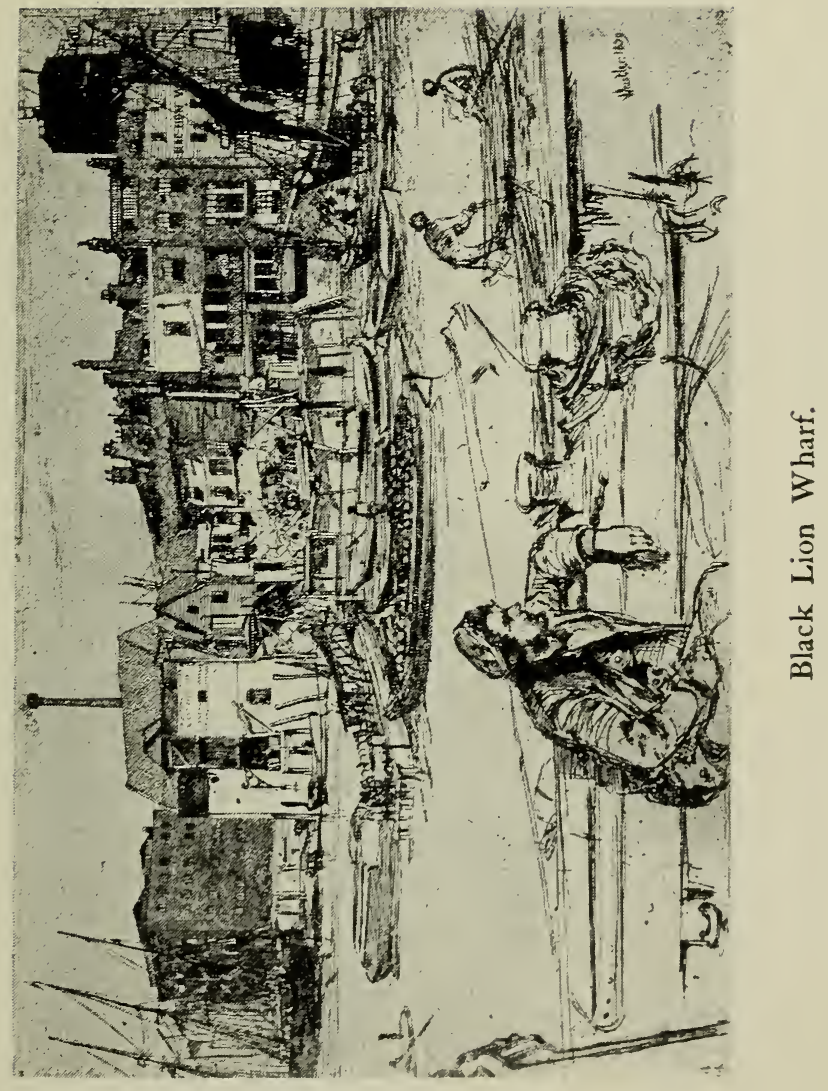





\section{MR. WHISTLER'S ETCHINGS By JOSEPH PENNELL}

\section{The Editor of the Daily Chronicle.}

LONDON.

Sir-Mr. Whistler's plate, "Black "Lion Wharf," or "The Black Lion," a reproduction of which is, I believe, to be published in to-day's Chronicle, is one of the greatest engraved plates that has been produced in modern times. I would even say that it is the greatest etching of modern times were it not for the fact that it is but one of a set known as "The Thames Series," etched by the master some thirty-five years ago. This "Thames Series," although not, as I propose to point out, the first etched work of Mr. Whistler, is, however, the first of that long succession of series which he has been issuing from that time until the present. ${ }^{1}$

In the Thames plates, it was Mr. Whistler's aim to show the river as it was in I859, and each one of them is a little portrait of a place, a perfect work of art. For the rendering, as $\mathrm{Mr}$. Whistler has rendered them, of these old houses in which every

1 Whistler died in London on the r7th of July, 1903. 
brick and every tile has been studied, every window frame rightly drawn, every bit of color truly suggested, is as much portraiture, and as difficult to accomplish, as to give the portrait of the old lighterman sitting in his barge. So difficult is it, indeed, that but two men in the whole history of the world have done such a thing. The one a Dutchman of the seventeenth century, the other an American happily living and working to-day. The one, Rembrandt, died virtually uncared for and ignored by his contemporaries; if the other lives and still works, it is only because he has the courage of a great artist, which has enabled him, during a whole lifetime, to fight through the insults and abuse that have been hurled at him unceasingly from the highest critical authority in England, as John Ruskin was considered at one time, to the veriest half-penny a liner; none was too high or too low to revile this artist, the man who certainly-we all know it now-will carry on the traditions of art to future generations. Now everything that he has produced is perfect, he is told; but as he himself has said, if it has been found good to-day, why was it not also good at the time it was brought forth?

As I have said, these etchings are perfect portraits of the London that we of the 


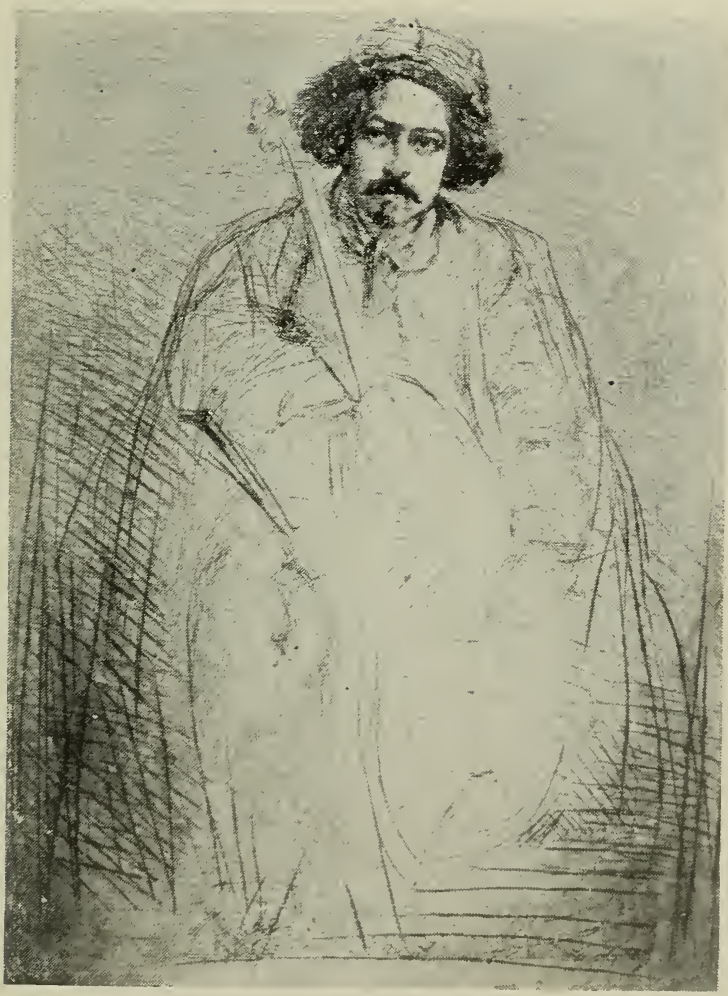

Becquet (The Fiddler) 



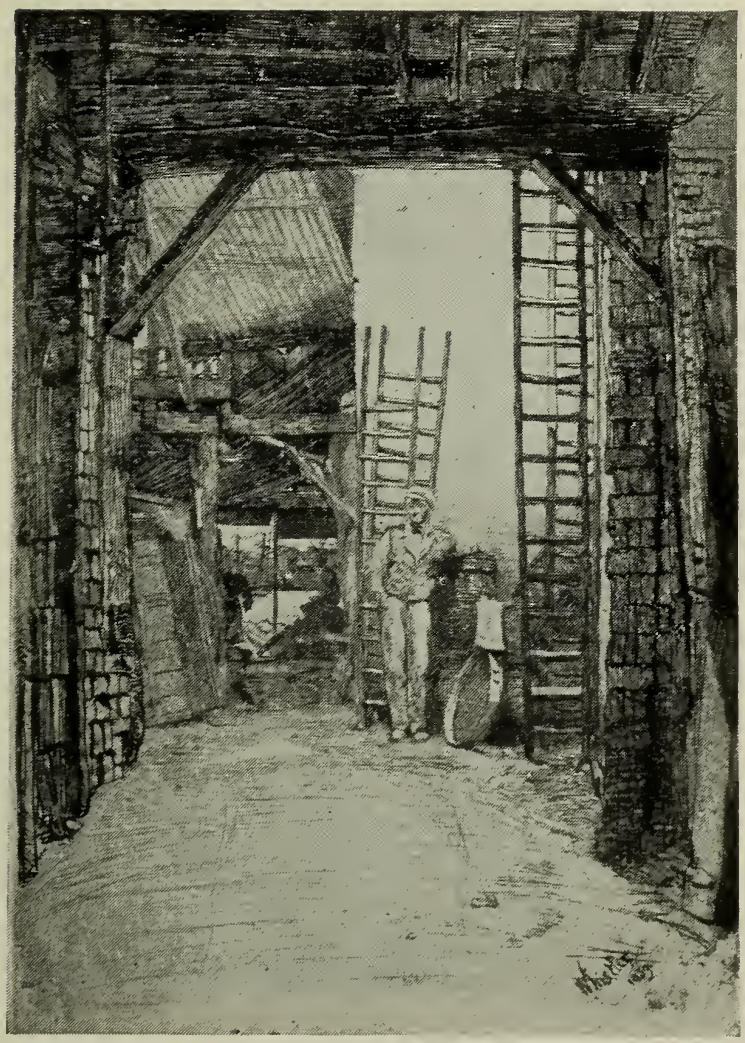

The Lime-Burner. 


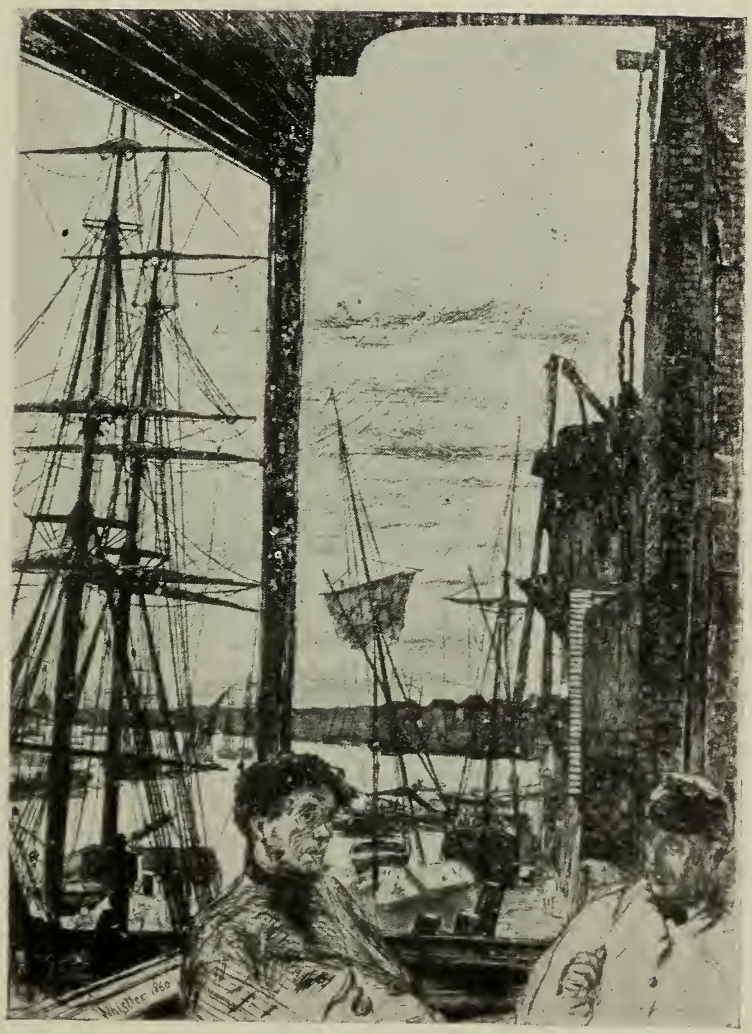

Rotherhithe (Wapping). 



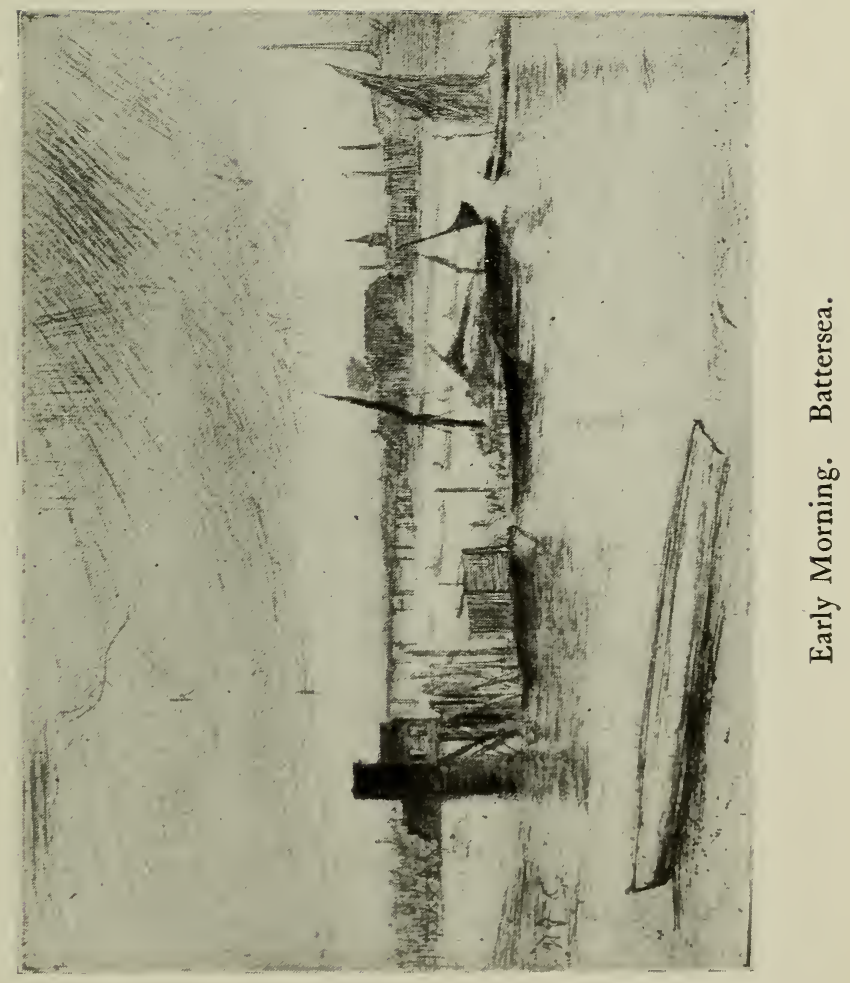



younger generation have never seen, but Mr. Whistler has made it so real for us that it will live forever. We may talk of Hollar, of Canaletto, of Piranesi, of Hogarth, but not even that master makes us feel the reality of London as Mr. Whistler does.

Among the other plates in the same set, are the "Forge," a dry point, excessively rare; the "Limehouse," a view down the Reach at low tide, with tangled barges lying in the mud; "The Lime-Burner," with its beautiful suggestion of light and shade; "Wapping"; "Billingsgate," which even Mr. Hamerton was compelled to praise in a niggardly fashion, though to his last day he never had any true understanding of the art of Mr. Whistler. While this series alone is enough to win immortality for any man, it marks but one period in his life's work. The first etchings, I believe, that Mr. Whistler produced were a series of maps made for the United States Coast Survey, and in their original state are, I fancy, virtually unknown. At any rate I do not think they were ever published, as the artist and the chief of the survey had, I have heard, diametrically opposite opinions as to what a tree should look like in a map. Really the first series of plates, I think, is that known as "The French Series," possibly because, as I have always understood, it was 
made in Germany, though published in France. Among these are "The Unsafe Tenement," "The Cabaret," and several other plates perfectly well known. Next came many portraits and plates, from Chelsea to the Lower River, from Paris to London, among them the "Thames Series," which latter won for their author the strongest kind of recognition in the land of the other great etcher, Holland, if, at that time, nowhere else. Artists-I don't mean painters with titles before and after their names-have, however, alwars appreciated the art of Mr. Whistler.

But from I 860 to I880, although very many plates were made, I do not think Mr. Whistler brought out any consecutive series. About I88I he went to Venice, and after an absence from London of a year or more-his longest from the metropolis until he shook for ever the dust of this unappreciative place off his feet-he brought back some fifty or sixty coppers which are now called masterpieces-true, they always were by artistsbut were then known as "another crop of Mr. Whistler's little jokes," by that truthful person, Henry Labouchere. This, however, was mild. A chorus of abuse was uttered by Frederick Wedmore, P. G. Hamerton, Harry Quilter, and many others, who, fortunately for themselves, did not sign their names. But 


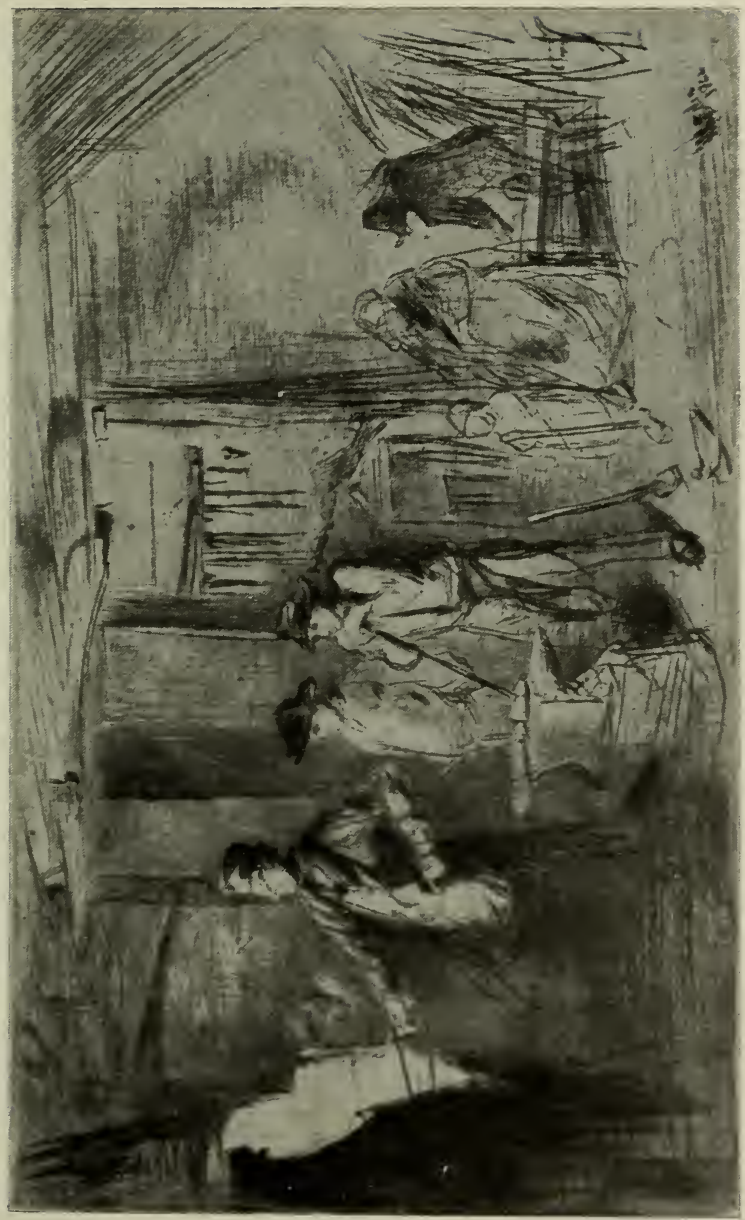

0
0
0
0
0
10 



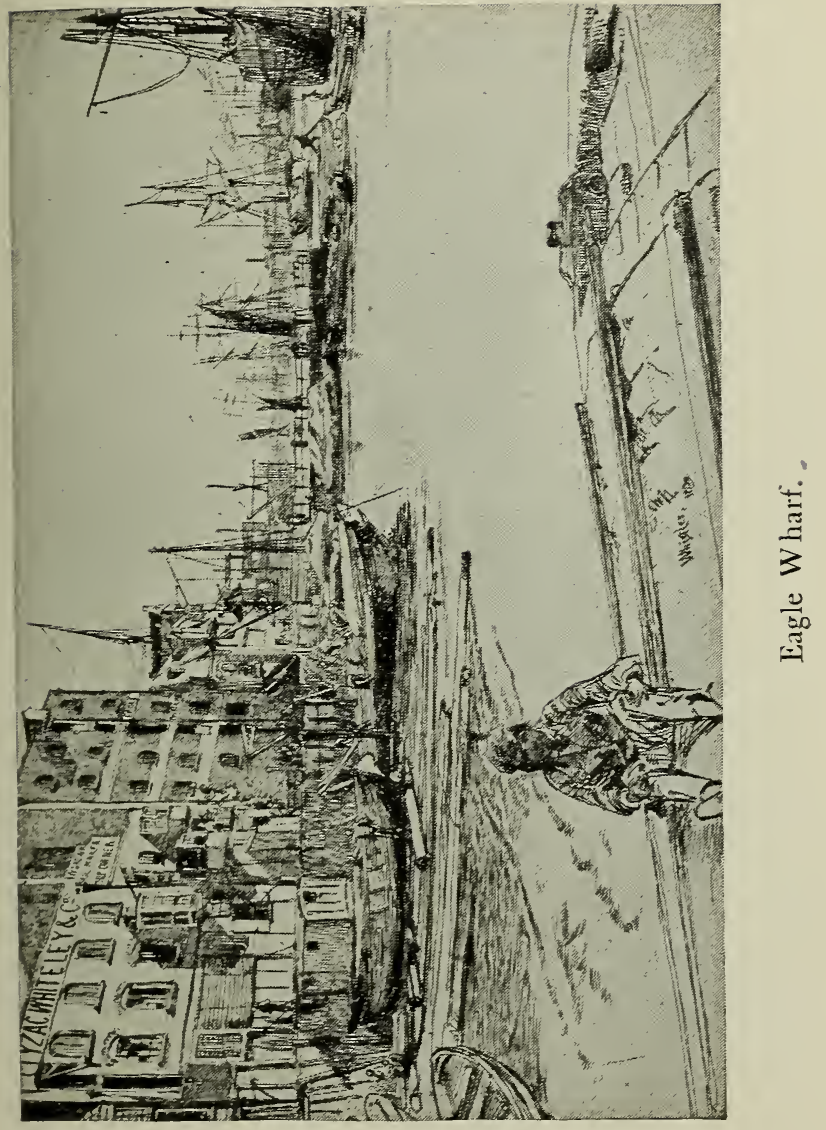





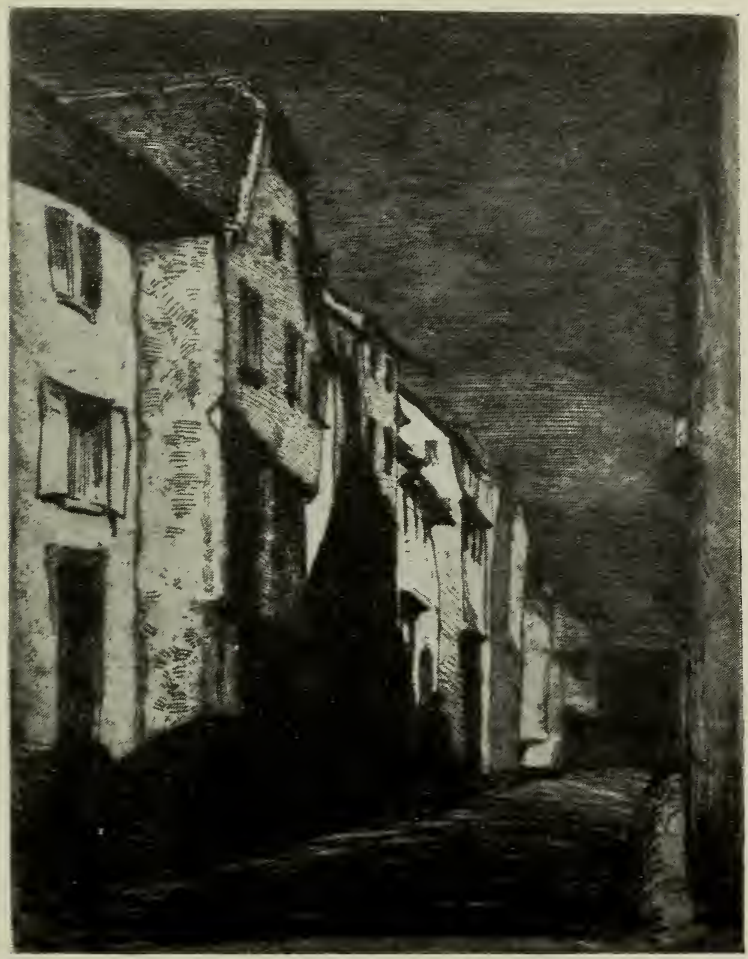

Street at Saverne. 



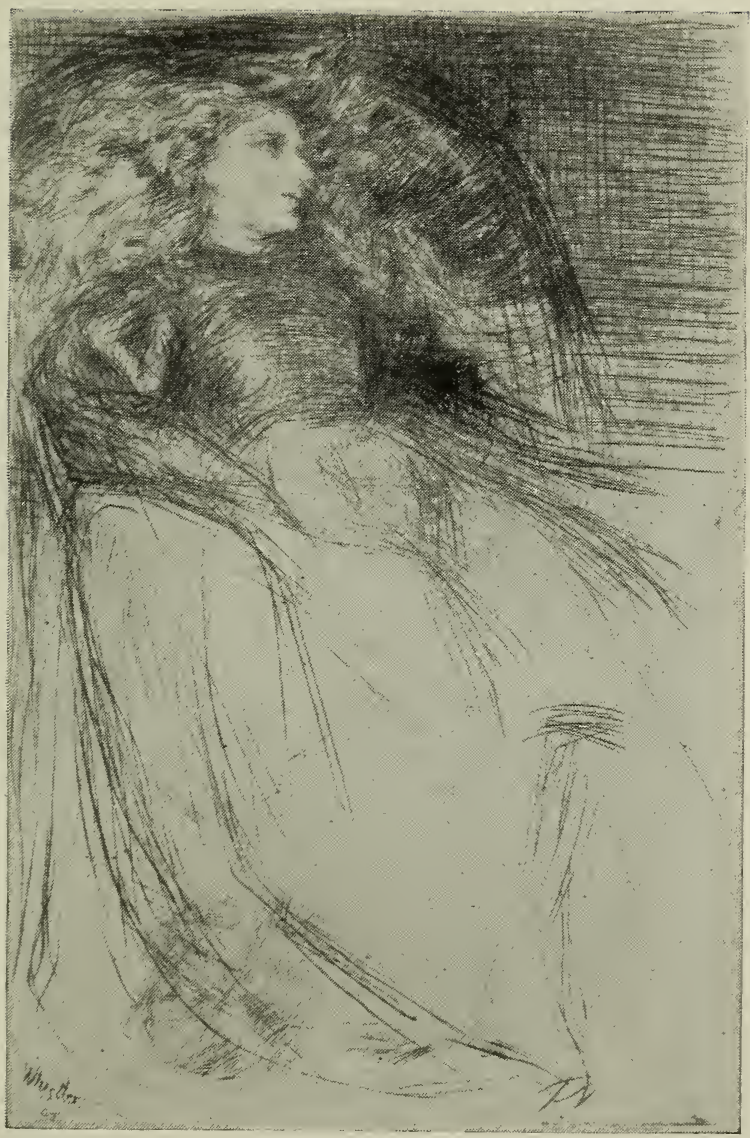

\section{Weary.}



those who did have ever since been trying to the best of their ability to prove that, whenever they write about Mr. Whistler, they always make themselves ridiculous. Since then Mr. Whistler has gone on steadily working. Several plates were done in provincial France; still others in Holland. One or two studies of long lines of canals, windmills in the distance, are in feeling much the same as Rembrandt, but in line much superior to Mr. Whistler's only rival. In fact, Sir Francis Seymour Haden said not very long ago that if he were compelled to give up his Rembrandts or his Whistlers, the Rembrandts would go first-an appreciation that was certainly genuine. After the French work came a Belgian set; but I am not sure if these have ever been regularly published; and I do not believe I am revealing any secrets when I say that I have seen the first proofs of another French series which, when they are issued, will delight the handful of people who know, by their beauty of line, their grace of subject, their exquisite handling. In this last Paris series, when the world sees it, all save the critics will be compelled to acknowledge that here are consummate plates by the master. All his work is alike perfect. It has only been produced under different circumstances, and is an attempt to render different effects or 
situations. Therefore the methods vary, but the results are always the same-great. Consequently the "Black Lion Wharf" is appropriate, not only as an illustration of the riverside of London a quarter of a century ago, but as showing a characteristic example of the marvelous work of the master. And it proves conclusively also, as I have pointed out before, as The Daily Chronicle has pointed out as well, that great artists to-day, in showing their work to the public through the Press, are doing but what the great masters of the past did when they showed theirs to the same public through the Church. I do not expect the critics to understand me-that, however, is unimportant. But I would say to the readers of The Daily Chronicle that never in the history of the world has there been such a series of remarkable drawings published by a daily paper, and never before have two great artists like Mr. Whistler and Sir Edward Burne-Jones contributed to a daily journal. Their motives may have been deliberately mis-stated, but one of their real reasons is their interest in the most striking experiment in modern journalism. There is another point which this plate of Mr. Whistler's emphasizes-that work which is really good looks well under any conditions.

London, February 22, 1895. 


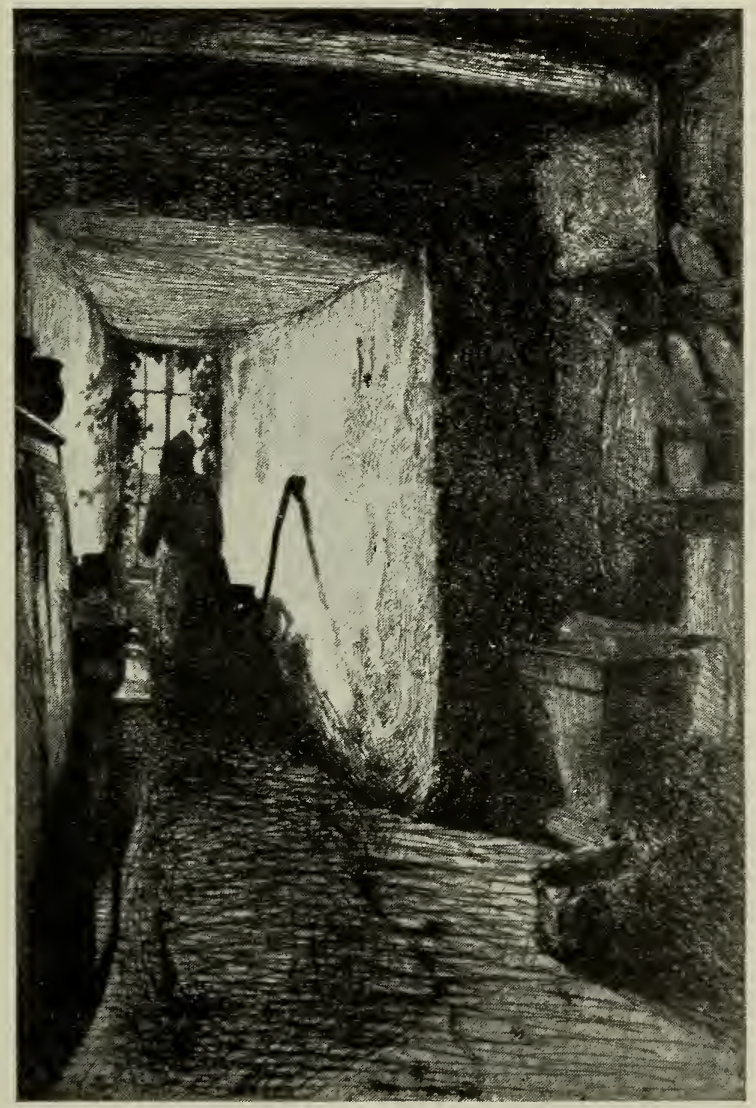

The Kitchen. 



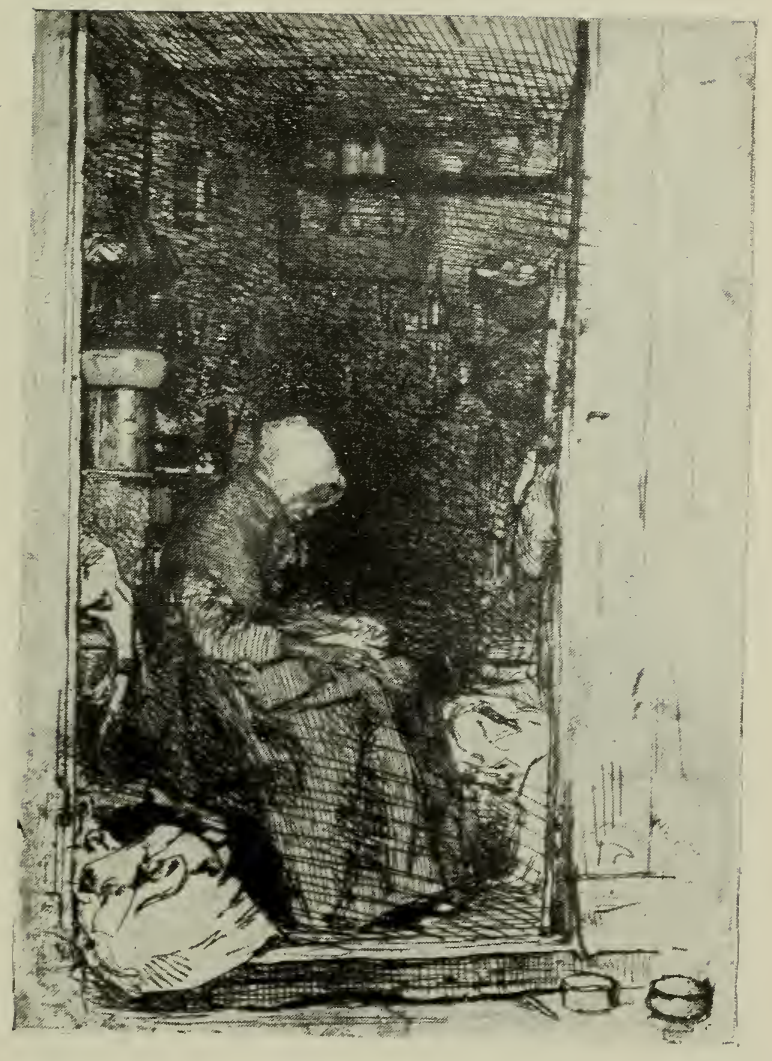

La Vieille aux Loques. 



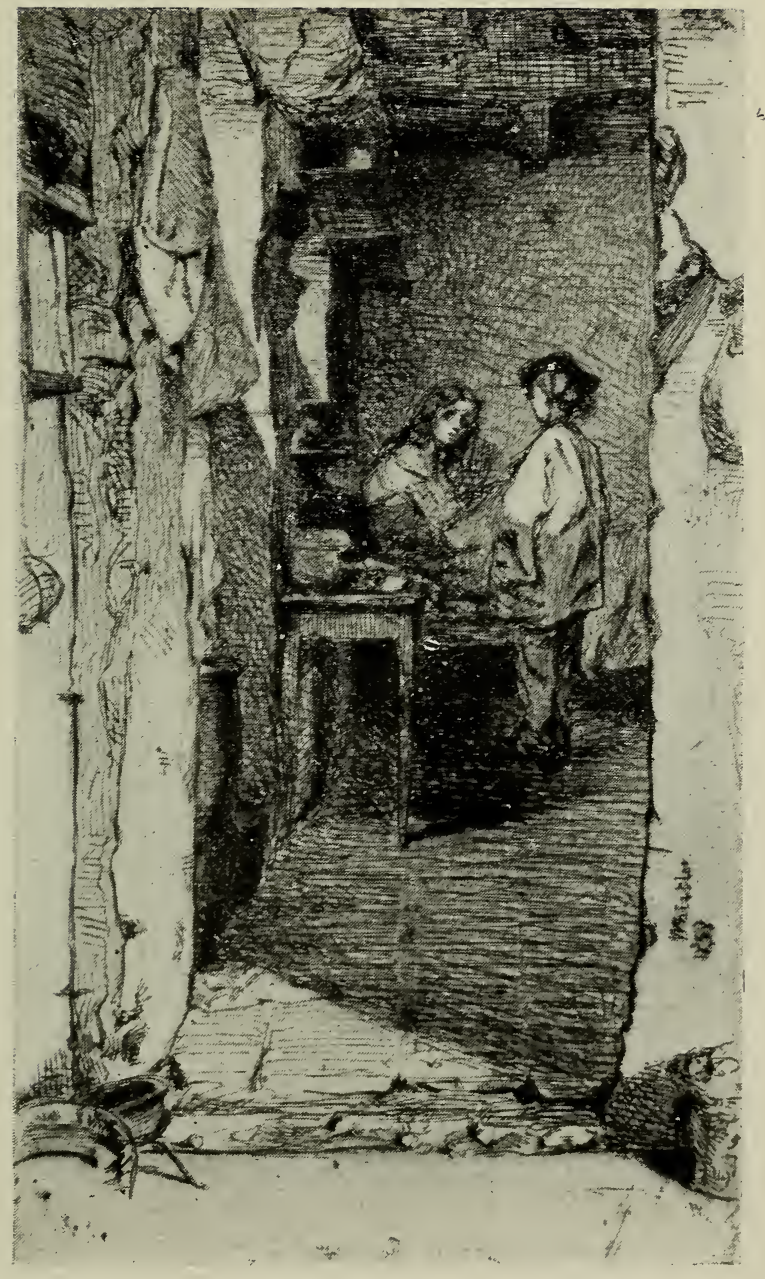

Rag Gatherers. 



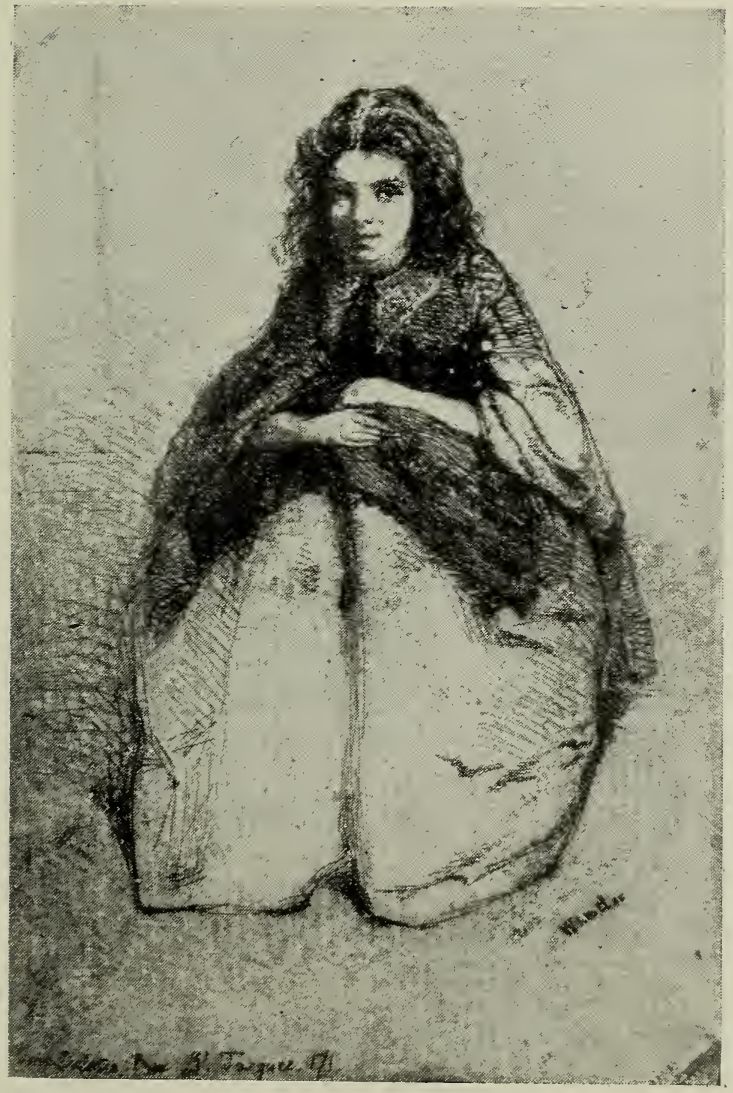

Fumette. 



\section{WHISTLER'S THAMES ETCHINGS}

$$
\text { BY MONSIEUR F. COURBOIN }
$$

ASSISTANT CURATOR OF THE PARIS PUBLIC COLLECTION OF PRINTS AND DRAWINGS

REPRINTED FROM THE BULLETIN DE L'ART ANCIEN ET MODERAE, PARIS, DECEMBER, I9O3

\section{LA}

\section{"SUITE DE LA TAMISE"}

DE J. MCN. WHISTLER

Dans ses Graveurs du XIX siècle, M. Henri Beraldi, après avoir constaté que les estampes de Whistler ne sont pas communes en France, ajoute cette petite phrase: "Le Cabinet des estampes n'en possède aucune."

Le Cabinet des estampes s'est amendé depuis cette constatation; il possède aujourd'hui quelques eaux-fortes de Whistler et notamment une "Suite de la Tamise," dont les excellentes épreuves offrent pour l'histoire de la gravure au xixe siècle un certain intérêt de curiosité. On sait que Whistler avait commencé par tirer lui-même quelques belles épreuves d'artiste, avant l'édition défectueuse publiée en I87I; puis, que les planches, re- 
prises par la Fine Art Society, avaient donné des épreuves suffisantes entre les mains du fameux imprimeur Goulding.

Nous devons de connaître la suite de leur histoire à l'obligeante communication de $\mathbf{M}$. Frederick Keppel, qui emploie autant de courtoisie que de sagacité à traîner vers son magasin de New-York les belles estampes de notre vieux continent.

Rappelons, pour les amateurs qui ne sont point nécessairement au courant des procédés du tirage de l'eau-forte, que, pour éviter l'usure trop rapide d'une planche de cuivre gravé, on commence par la recouvrir, au moyen d'un bain galvanique, d'une mince couche d'acier: c'est ce qu'on appelle l'aciérage. Les premiers essais de ce procédé, qui a causé une révolution dans l'art de la gravure du xix siècle, ont coïncidé avec les premières eaux-fortes de Whistler(1857). Aujourd'hui, la technique de l'aciérage est bien établie, et le moindre imprimeur en taille douce est capable d'aciérer lui-même les planches qu'on lui donne à tirer; mais, voilà quarante ans, on se méfiait, et l'aciérage courait le risque d'être-tout comme le fameux pont d'Asnières -trop solidement fait. C'est ce qui arriva au planches de Whistler, et la fâcheuse édition de I87I n'est mauvaise que parce quon a exagéré les précautions prises pour la faire bonne. 


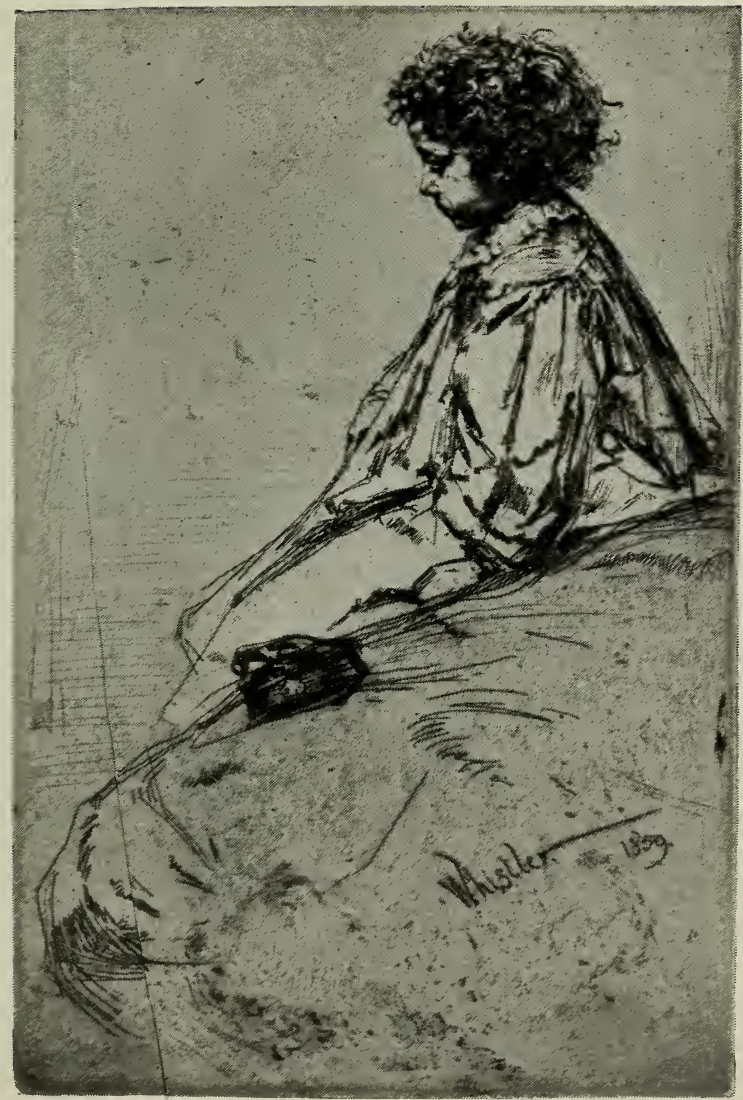

Bibi Lalouette. 


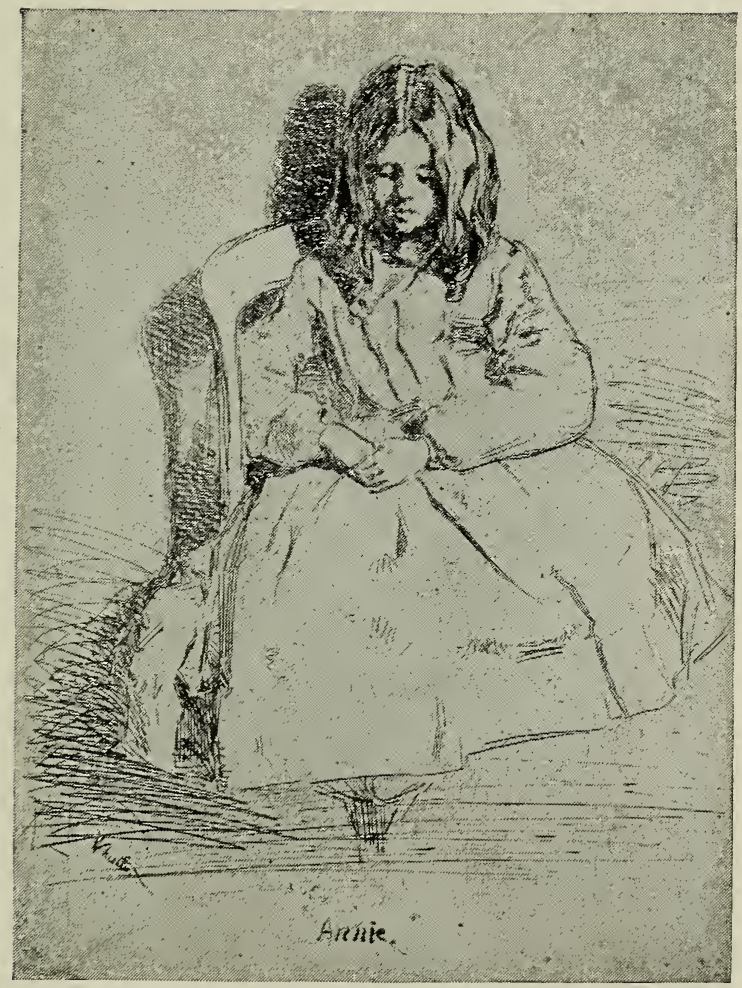

Annie, seated. 



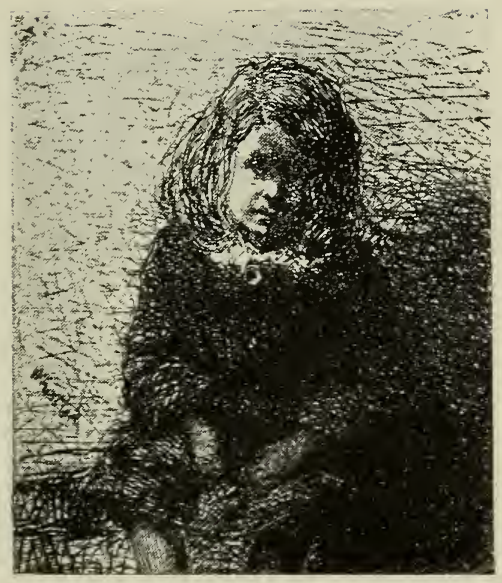

Little Arthur. 

En examinant ces planches, Frederick Keppel pensa que, sous leur "blindage," les cuivres devaient être en aussi bon état qu'au moment où Whistler en tirait ses belles épreuves d'artiste; il n'hésita donc pas à acheter la "suite" et à faire immédiatement désaciérer les planches. Il avait deviné juste: les cuivres de Whistler avaient été sauvés par leur couche d'acier, comme ceux de Van Dyck l'avaient autrefois été par l'encre oubliée et durcie dans les tailles. C'est un peu l'histoire de l'affreux badigeon qui a conservé tant de fines boiseries et auquel on est si reconnaissant ... quand il est bien parti.

Ajoutons que Whistler, en voyant les excellentes épreuves que donnaient de nouveau ses planches, manifesta une violente surprise - on sait que le maître avait des façons à lui de manifester-et que Frederick Keppel, après avoir fait tirer sur les "cuivres nus" le nombre restreint de très belles épreuves que ces cuivres pouvaient donner, biffa irrémédiablement les planches pour éviter toute possibilité de tirage médiocre à l'avenir.

C'est ainsi que, s'il n'a pas les rarissimes épreuves tirées par Whistler lui-même, le Cabinet des estampes possède, de la "suite de Tamise," des épreuves très supérieures à celles qui ont été mises dans le commerce. 
THE FOLLOWING ETCHINGS BY

IIR. WHISTLER MAY AT PRESENT BE SEEN IN

THE STOCK OF

MESSRS. FREDERICK KEPPEL \& CO., 4 EAST 39th STREET,

NEW YORK.

February 15, IQIO.

\section{THE THAMES SERIES}

Becquet (The Fiddler) (See Illustration) Black Lion Wharf (See Illustration)

Chelsea Bridge and Church

Eagle Wharf (See Illustration)

Early Morning. Battersea

Limehouse

Millbank

Old Hungerford Bridge

Rotherhithe (Wapping) (See Illustration)

Thames Police (Custom House)

Thames Warehouses

The Forge (See Illustration)

The Lime-Burner (See Illustration)

'The Little Pool

The Pool

Westminster Bridge 


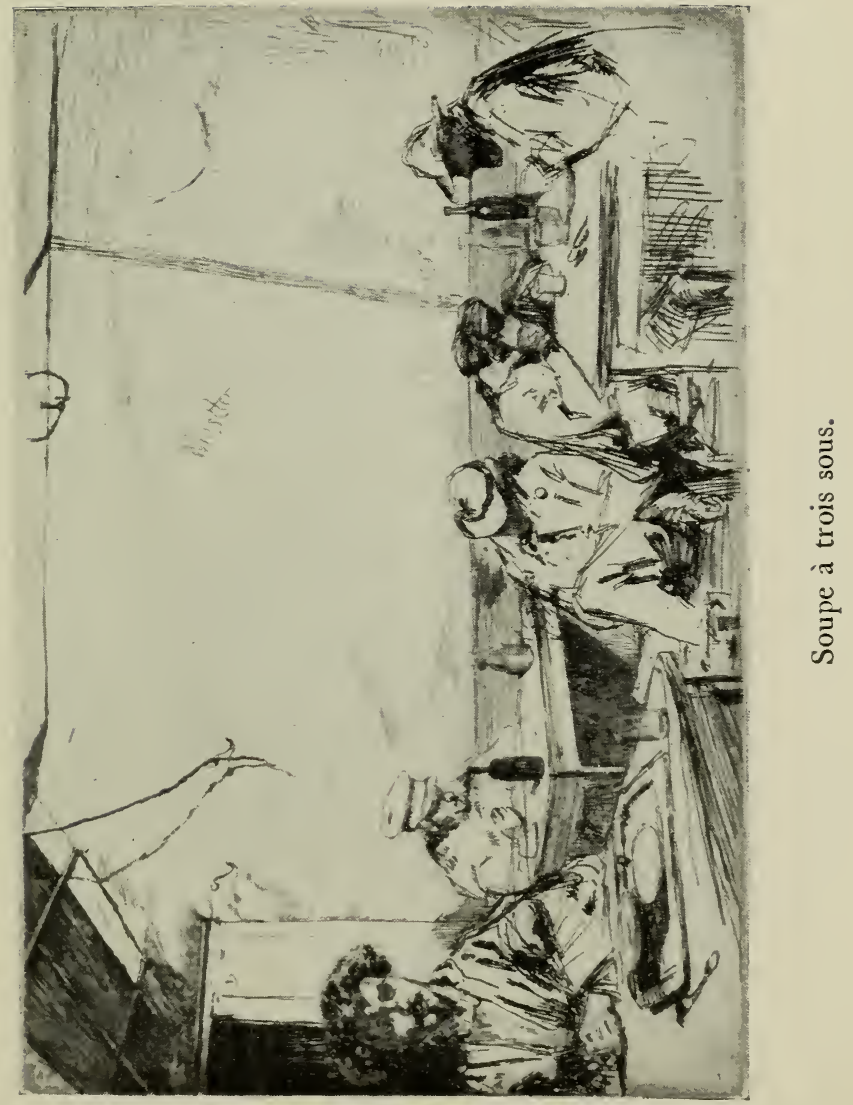





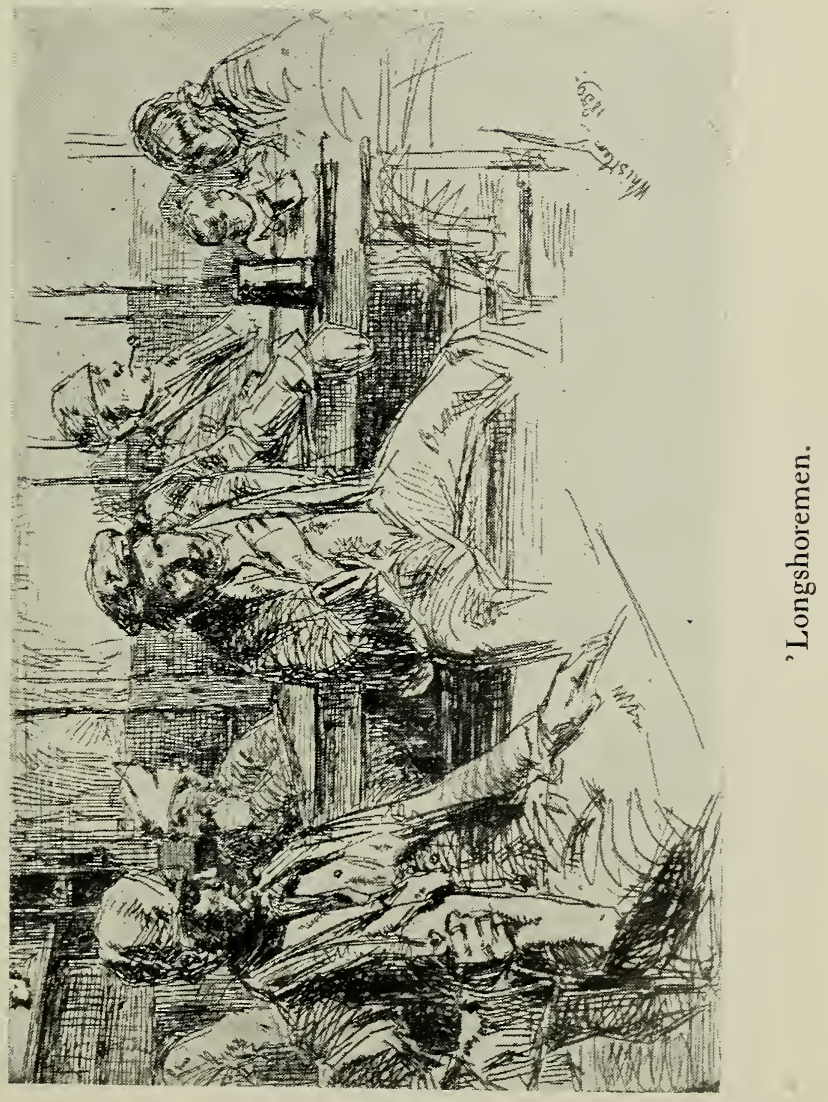





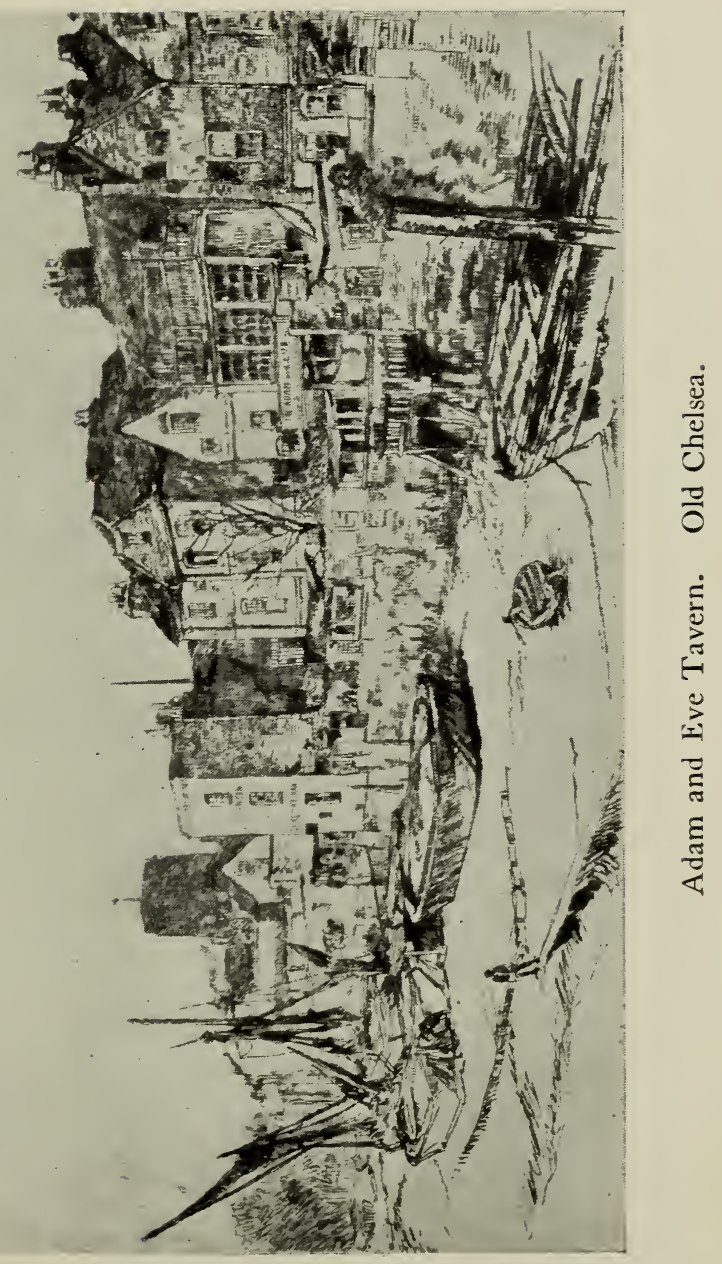





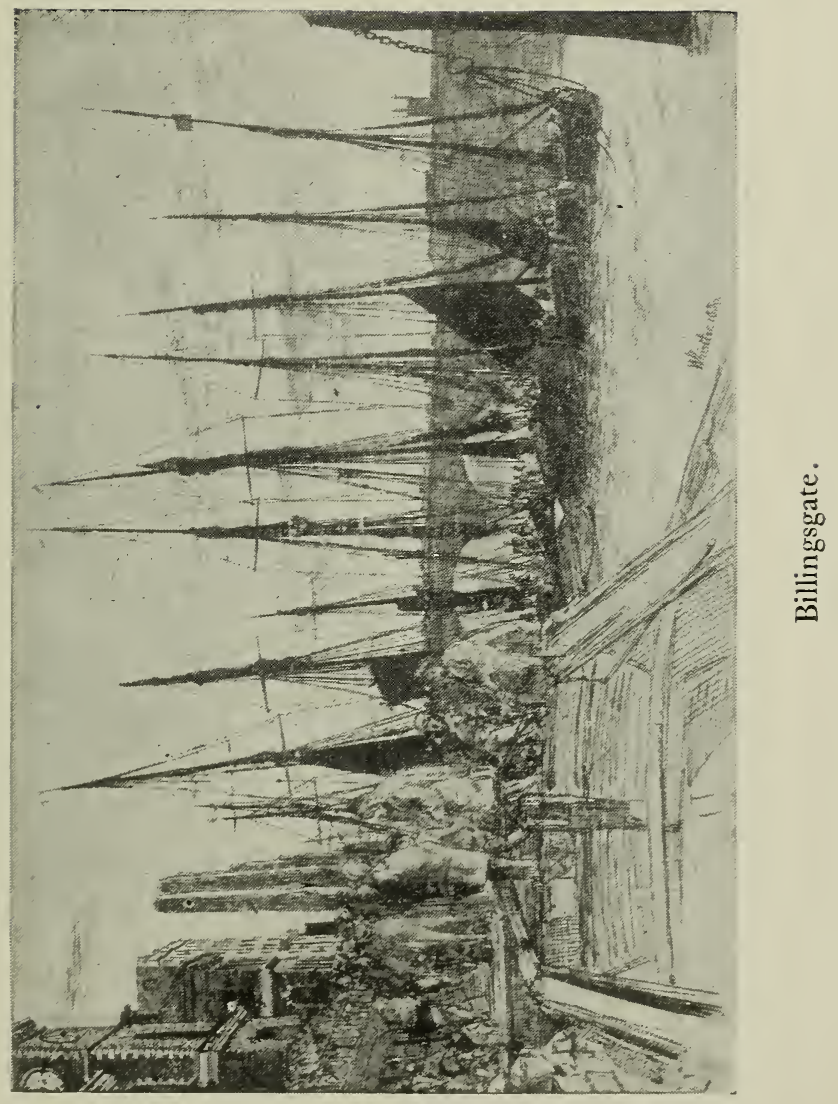



Adam and Eve Tavern. Old Chelsea (See Illustration)

Amsterdam from the Tolhuis

Annie

Annie, seated (See Illustration)

Bibi Lalouette (See Illustration)

Bibi Valentin (See Illustration)

Billingsgate (See Illustration)

Boy, The

Doorway and Vine

Doorway, The

Dordrecht

Florence Leyland

Fulham

Fumette (See Illustration)

Garden, The

Greenwich Park (See Illustration)

Greenwich Pensioner

Joe's Bent Head

Kitchen, The (See Illustration)

Landscape with the Horse, The 
Little Arthur (See Illustration)

Little Boy, A

Little Forge, The

Little Lagoon

Little Mast

Little Smithfield

Liverdun

Lobster Pots

'Longshoremen (See Illustration)

Mère Gérard, La

Model Resting, The

Music Room, The

Nocturne

Nursemaid and Child

Piazetta

Price's Candle Works

Putney Bridge

Quiet Canal

Rag Gatherers, The (See Illustration)

Reading in Bed

Rétameuse, La

Riva, The: No. One

Saiute: Dawn

San Biagio 


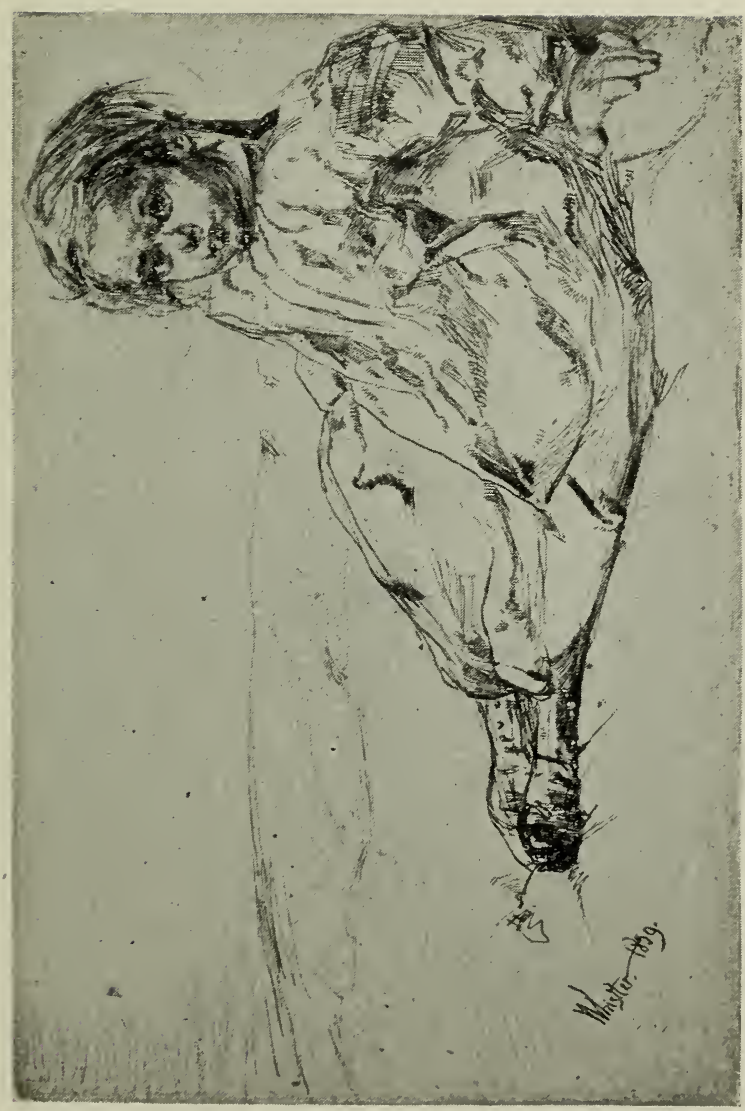

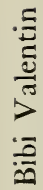





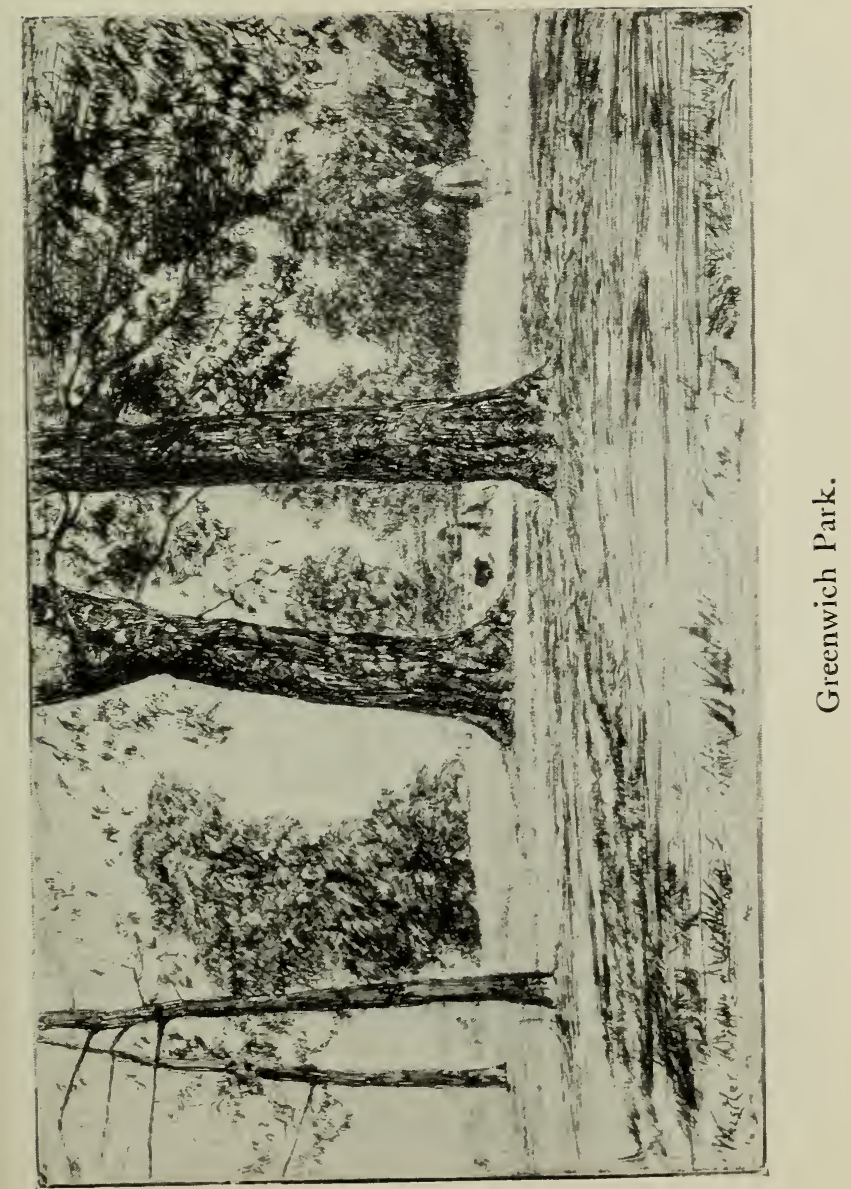





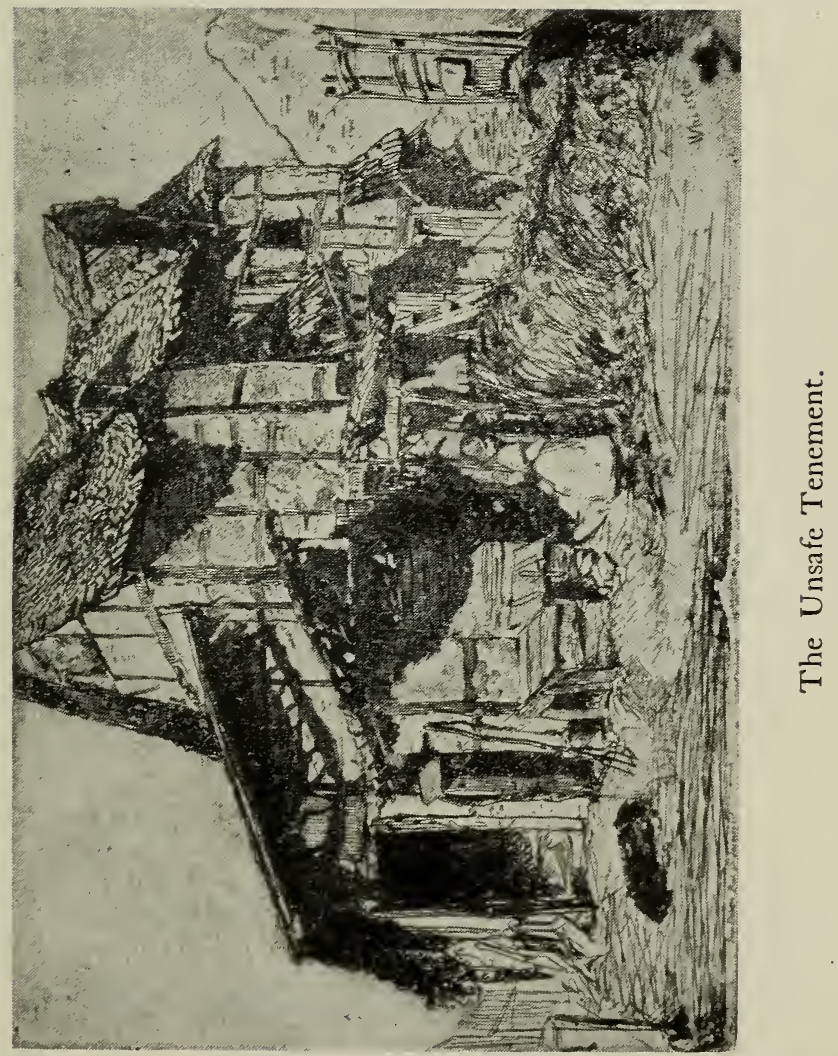





\section{San Giorgio}

Seymour

Ship Builder's Yard

Smithy

St. James's Place, Houndsditch

Street at Saverne (See Illustration)

Thames toward Erith

Title to French Set

Turkeys

Two Ships

Unsafe Tenement, The (See Illustration)

Upright Venice

Vauxhall Bridge

Velvet Dress

Vieille aux Loques, La (See Illustration)

Weary (See Illustration)

Wine Glass, The 



\section{.}


SMITHSONIAN INSTITUTION LIBRARIES

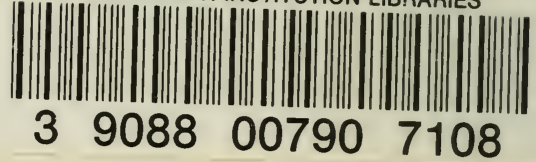


